УДК 378.147:004:795

DOI:

Петро Волянський, доктор наук з державного управління, доиент, начальник Інституту державного управління у сфері изивільного захисту

Юрій Ковровський, кандидат психологічних наук, дочент кафедри державної служби, управління та навчання за міжнародними проектами Інституту державного управління у сфері ичивільного захисту

Віктор Михайлов, кандидат наук з державного управління, професор кафедри державної служби, управління та навчання за міжнародними проектами Інституту державного управління у сфері ичивільного захисту

\title{
ЗАСТОСУВАННЯ ІНТЕРАКТИВНИХ ОСВІТНІХ ТЕХНОЛОГІЙ У НАВЧАННІ КЕРІВНОГО СКЛАДУ І ФАХІВЦІВ, ДІЯЛЬНІСТЬ ЯКИХ ПОВ'ЯЗАНА 3 ОРГАНІЗАЦІЮЮ ТА ЗДІЙСНЕННЯМ ЗАХОДІВ 3 ПИТАНЬ ЦИВІЛЬНОГО ЗАХИСТУ
}

У статті розглядається можливість застосування сучасних інтерактивних освітніх технологій у навчанні керівного складу і фахівців, діяльність яких пов'язана з організацією та здійсненням заходів з питань ичвільного захисту. Окреслено ряд професійних компетентностей фахівиів відповідної сфери, розвитку яких сприяє застосування інтерактивних освітніх технологій, зокрема, кейс-технології. Описано зміст і структуру розробленого авторами комплексного навчального кейсу, а також розкрито алгоритм його проведення, в рамках реалізації програми короткострокового підвищення кваліфікації з питань ицвільного захисту. Наведено дані про результати впровадження кейс-технології в освітній процес за допомогою розробленого навчально-методичного інструментарію.

Ключові слова: інтерактивні освітні технологї; кейс-технологія; професійна компетентність; изивільний захист; безпека життєдіяльності; надзвичайні ситуації.

Рис. 1. Табл. 1. Лім. 11.

Petro Volyanskiy, Doctor of Sciences (Public Administration), Associate Professor, Acting Director of the Institute of Public Administration in the Sphere of Civil Defense

Yuriy Kovrovskiy, Ph.D.(Psychological Science), Associate Professor of the Public Service, Management and Training according to International Projects Department The Institute of Public Administration in the Sphere of Civil Protection Victor Mykhaylov, Ph.D.(Public Administration), Professor of the Public Service, Management and Training according to International Projects Department The Institute of Public Administration in the Sphere of Civil Protection

\section{USING THE INTERACTIVE TRAINING TECHNOLOGIES IN PROFESSIONAL PREPARATION FOR PROFESSIONALS IN THE SPHERE OF CIVIL PROTECTION}

The article deals with the possibility of using the modern interactive educational technologies for the training of top-management and specialists whose professional activity is related with organization and implementation of civil protection measures. The authors determine a number of professional competencies of specialists of abovementioned sphere for development of which is facilitated by the use of interactive educational technologies, in particular, case technology. In the article the content and structure of complex training, as well as the algorithm of its carrying out is described. This complex training was designed within the framework of the program of short-term qualification improvement for civil protection. The data on the results of case-technology implementation in the educational process, using the developed educational and methodological tools, are presented. The peculiarities of practical classes using the method of analysis of specific educational situations on the topic "Coordination of activities related to technological-ecological protection of population and territories, prevention and response to emergency situations" are considered. The authors describe a content of the main stages and structural components of the lesson: the aims, the ways of conducting, a content of information materials, a main task for the audience, regulatory and legal base, a block of short situational exercises. In the article the criteria for evaluating the results of initial activity of students during the execution of situational tasks are determined. The authors also describe the 
organization and methodology of the pedagogical experiment. Prospects for further research are outlined - to create a dynamic learning model of emergency development for reproduction by means of SMART Board.

Keywords: interactive educational technologies; case technology; professional competence; civil protection; life safety; emergency.

П остановка проблеми. В умовах інтенсифікації впливуна життєдіяльність людини багатьох небезпечних факторів зовнішнього середовища, що виникають внаслідок масштабних небезпечних подій різного характеру, особливої значущості набувають питання щодо професійної підготовки керівного складу і фахівців, діяльність яких пов'язана 3 організацією та здійсненням заходів з питань цивільного захисту. Разом 3 тим існуюча система функціонального навчання не здатна задовольняти зростаючі вимоги сьогодення до рівня професійної компетентності посадових осіб органів державної влади 3 питань цивільного захисту. Вирішення даної проблеми вбачається у впровадженні сучасних інтерактивних освітніх технологій у навчальний процес, що загалом сприятиме підвищенню ефективності навчання 3 питань цивільного захисту та, зокрема, вдосконаленню професійних компетентностей слухачів.

Отже, актуальним на сьогоднішній день постає питання модернізації освіти у сфері цивільного захисту на новій концептуальній основі, використовуючи компетентнісний підхід. Найбільш ефективною інтерактивною технологією для вирішення поставленого завдання нами визначено метод аналізу конкретних навчальних ситуацій.

Аналіз останніх досліджень і публікацій. Розробка і використання кейс-технології було започатковано у Гарвардському університеті на початку XX століття. Після успішної апробації в США методика поширилася і на європейський освітній простір. 31992 року метод кейсів використовується у вітчизняній освіті. Вперше ця технологія була впроваджена серед майбутніх фахівців з державного управління. Спочатку кейстехнологія застосовувалась в Україні для підготовки фахівців економічного спрямування, проте на сьогоднішній день вона набула поширення практично у всіх фахових напрямках професійної підготовки.

Проблема застосування кейс-технології в сучасній освіті знайшла своє відображення в дослідженнях як вітчизняних, так і зарубіжних учених, а саме Ю. Сурміна, В. Лободи, О. Сидоренка, М. Білінської, І. Дичківської, Г. В. Гребенькової, В. Лозової, Л. Анисимової, О. Дубасенюк, О. Пометун, М. Урбант, О. Смоляніної та ін.

Разом 3 тим, особливості розробки i застосування кейс-технології у підготовці керівного складу і фахівців, діяльність яких пов'язана з організацією та здійсненням заходів 3 питань цивільного захисту, раніше не виступали предметом окремих досліджень.

Мета статті. Аналіз особливостей розробки і застосування кейс-технології для підготовки керівного складу і фахівців, діяльність яких пов'язана з організацією та здійсненням заходів 3 питань цивільного захисту.

Відповідно до Конституції України життя i здоров'я людини, іiї захищеність від впливу шкідливих техногенних, природних, екологічних і соціальних факторів $\epsilon$ найвищими соціальними цінностями, для забезпечення яких створено Єдину державну систему цивільного захисту (далі - ЄДС ЦЗ). Цивільний захист, як функція держави, спрямована на захист населення, територій, навколишнього природного середовища та майна від надзвичайних ситуацій шляхом запобігання таким ситуаціям, ліквідації їх наслідків і надання допомоги постраждалим у мирний час та в особливий період [3].

Загальна характеристика професійної діяльності визначає вимоги до професійної компетентності фахівців і керівного складу органів державної влади для ефективного здійснення ними управлінських функцій та обов'язків у сфері цивільного захисту, беручи до уваги не лише освітньо-кваліфікаційний рівень та стаж, ай досвід роботи, володіння спеціальними знаннями, уміннями і навичками, необхідними для ефективної професійної діяльності, обов'язків у сфері цивільного захисту за займаною посадою, з врахуванням природних і техногенно-екологічних особливостей регіону, практики ведення цивільного захисту, режимів функціонування територіальних підсистем ЄДС ЦЗ та специфіки виконання завдань щодо запобігання і реагування на надзвичайні ситуації, інших особливостей регіону або вимог роботодавця.

Аналіз основних повноважень органів державної влади у сфері цивільного захисту та кваліфікаційних вимог до керівного складу і фахівців, діяльність яких пов'язана з організацією та здійсненням заходів з питань цивільного захисту [6], дав можливість в загальному вигляді виокремити основні компетенції зазначеної категорії службовців з питань цивільного захисту, a саме:

- планування та забезпечення виконання заходів цивільного захисту в усіх режимах 
функціонування територіальної підсистеми єДСЦЗ;

- підтримання у готовності автоматизованих систем централізованого оповіщення населення про загрозу або виникнення надзвичайних ситуацій;

- здійснення керівництва аварійнорятувальними та іншими невідкладними роботами;

- організація та забезпечення евакозаходів, укриття населення в захисних спорудах;

- здійснення керівництва створеними аварійнорятувальними службами, спеціалізованими службами та формуваннями цивільного захисту;

- взаємодія 3 іншими структурами та формуваннями СДС ЦЗ;

- визначення збитків, які сталися внаслідок надзвичайних ситуацій, а також порядку підготовки документів для отримання матеріальної та фінансової допомоги;

- організація здійснення постійного моніторингу і прогнозування зони можливого поширення надзвичайної ситуації та масштабів можливих іiї наслідків;

- організація і здійснення радіаційного, хімічного, біологічного, інженерного та медичного захисту населення і територій від наслідків надзвичайної ситуації;

- мобілізація та використання ресурсів підприємств, установ і організацій, незалежно від форм власності, для відвертання небезпеки та ліквідації надзвичайних ситуацій з обов'язковою компенсацією понесених втрат;

- забезпечення зміни режиму роботи підприємств, установ, організацій усіх форм власності, переорієнтація їх на виробництво необхідної в умовах надзвичайного стану продукції, інші зміни виробничої діяльності, необхідні для проведення аварійно-рятувальних і відновлювальних робіт.

Проведений аналіз показує складність і масштабність виконуваних завдань, високий ступінь відповідальності, необхідність опрацьовувати рішення в умовах надзвичайних ситуацій різного характеру при швидкій зміні оперативної обстановки та браку часу і ресурсів зумовлюють специфічні вимоги до підготовки слухачів, які повинні володіти певними компетентностями у сфері цивільного захисту.

Таким чином, теоретичний аналіз особливостей професійної діяльності фахівців сфери цивільного захисту з урахуванням досвіду підвищення кваліфікації даної категорії слухачів дозволяє сформувати гіпотезу про те, що найбільш ефективними освітніми технологіями для формування необхідних компетентностей для сфери цивільного захисту є інтерактивні методи навчання, зокрема, кейс-технології.

Кейс-технологія (від англ. Case - випадок, ситуація) $є$ сукупністю методів активного проблемно-ситуативного аналізу, заснованих на навчанні шляхом вирішення конкретних завдань - ситуацій (кейсів) та належить до неігрових імітаційних активних методів навчання. Одним 3 різновидів кейс-технології $\epsilon$ метод аналізу конкретних навчальних ситуацій. В основі використання кейс-технології лежить робота зі спеціально розробленими для конкретної дисципліни або заняття кейсами, проте у тлумаченні змісту поняття “кейс" у світовій і вітчизняній науці існують певні розбіжності.

Білоруська науковець М. Урбант у зміст поняття “кейс" вкладає епізод життєвої практики, що містить проблему і не має однозначного вирішення [10]. Відповідно вироблення варіантів вирішення є основним завданням будь-якого кейсу. На думку російського педагога О. Смоляніної кейс необхідно розглядати не просто як правдивий опис подій, а як єдиний інформаційний комплекс, який дозволяє зрозуміти ситуацію [8].

На думку ряду вітчизняних учених кейс-метод - це такий метод навчання, за якого студентам пропонується проаналізувати реальну життєву ситуацію. Опис цієї ситуації одночасно відображає не тільки певну практичну проблему, але й актуалізує певний комплекс знань, які необхідно засвоїти під час вирішення проблеми. При цьому сама проблема не має однозначного вирішення, являє собою особливий, розгалужений i неоднозначний оптимум.

Ю. Сурмін розглядає кейс як інтерактивний метод навчання, що базується на обговоренні деякого тексту, в якому відображається реальна неоднозначна ситуація в будь-якому виді людської діяльності [9].

Окрім того, на сьогоднішній день, існує значна кількість різноманітних наукових підходів до визначення класифікації, характерних ознак, цілей, функцій і можливостей, методики розробки, а також особливостей впровадження кейстехнології, проте зазначені проблеми є окремим предметом для наукових досліджень.

Отже, аналіз наукових джерел дає змогу представити кейс як опис певної реальної ситуації, яка реально відбулася (або могла відбутись) та описана розробником для того, щоб спровокувати дискусію та провести детальний аналіз 3 подальшим опрацюванням рішення колективом слухачів. Простіше кажучи, це такий метод навчання, за якого слухачам пропонується 


\section{ЗАСТОСУВАННЯ ІНТЕРАКТИВНИХ ОСВІТНІХ ТЕХНОЛОГІЙ У НАВЧАННІ КЕРІВНОГО СКЛАДУ І ФАХІВЦІВ, ДІЯЛЬНІСТЬ ЯКИХ ПОВ' ЯЗАНА 3 ОРГАНІЗАЦІЄЮ ТА ЗДІЙСНЕННЯМ ЗАХОДІВ 3 ПИТАНЬ ЦИВІЛЬНОГО ЗАХИСТУ}

проаналізувати реальну професійну ситуацію. Як зазначають вітчизняні педагоги, опис цієї ситуації одночасно відображає не тільки якусь практичну проблему, але й актуалізує певний комплекс знань, які необхідно засвоїти під час вирішення даної проблеми. При цьому сама проблема не має однозначного вирішення [4].

Суттєвим для підготовки фахівців у сфері цивільного захисту є те, що кейси застосовуються при закріпленні спеціальних знань та вмінь, розвиткові навичок комунікації, аналізу та критичного мислення, встановлення зв'язку теорії та практики. Результатом застосування методу $\epsilon$ не тільки знання, але й навички професійної діяльності. Серед стратегічних принципів розвитку методу case-study i впровадження його в освітні програми вітчизняна дослідниця 3. Скринник виділяє зокрема необхідність впровадження методу в програми підготовки фахівців за спеціальностями, в яких домінує ситуаційне знання і ситуаційна діяльність, таким як менеджмент, економіка, соціологія, маркетинг [5]. На нашу думку метод конкретних навчальних ситуацій може стати основною формою проведення практичних занять при підготовці керівного складу і фахівців сфери цивільного захисту, як такий, що цілком відповідає особливостям і вимогам даної професійної сфери: високий рівень стресостійкості, комунікативних навичок, знання основ кризового та ризикменеджменту, здатність до швидкого прийняття рішення в умовах невизначеності, браку часу та інформації, уміння імпровізувати, мислити нестандартно.

В Інституті державного управління у сфері цивільного захисту виконуються наукові дослідження з проблем навчання населення та впровадження інтерактивних освітніх технологій. Як результат наукових досліджень для більш глибокого й відповідно якісного вивчення програмної теми: “Координація діяльності, пов'язаної з техногенно-екологічною безпекою, захистом населення і територій, запобіганнями i реагуванням на надзвичайні ситуації” нами було розроблено навчально-методичний інструментарій для проведення практичного заняття за методом аналізу конкретних навчальних ситуацій 3 використанням інформаційно-комунікативних технологій, на якому передбачалося опрацювання основних завдань комісій $з$ питань техногенноекологічної безпеки та надзвичайних ситуацій на території відповідної адміністративнотериторіальної одиниці.

Спираючись на існуючі наукові підходи до класифікації кейсів, можемо констатувати, що розроблений навчально-методичний інструментарій відноситься до великих неструктурованих (long unstructured cases) кейсів так як характеризується великим обсягом навчального матеріалу i високою деталізацією даних для розгляду в межах конкретного сюжету розвитку подій. За типом застосування він $\epsilon$ навчальним адже призначений для підвищення ефективності освітньої діяльності і проводиться у формі рольової гри. Враховуючи специфіку сфери застосування даний кейс можна віднести до організаційно-інституційних адже учасники представляють організації, підприємства, установи та їх підрозділи [2].

В основу сюжету навчальної ситуації покладено явище, що передбачає різке погіршення стану справ у тієї чи іншої системи аж до іiі руйнування, а саме явище пов'язане 3 гідрологічними надзвичайними ситуаціями (повінь, паводок). Таким чином, спираючись на підхід Ю. Сурміна, розроблений кейс відноситься до типу “Криза”, зміст якої визначає загроза пріоритетним цілям і цінностям, гострий дефіцит часу для реагування на загрозу і відсутность єдиної моделі виходу із ситуації [9].

Збір необхідної інформації для підготовки методичного забезпечення здійснювався на підставі теоретичних досліджень, вивчення нормативно-правових актів 3 питань діяльності пов'язаної з техногенно-екологічною безпекою, захистом населення і територій, запобіганням i реагуванням на надзвичайні ситуації [7], а також вивчення змісту навчальних програм підвищення кваліфікації з питань цивільного захисту. При розробці навчальних матеріалів для конструювання навчальної ситуації практичного заняття використовувались не лише результати теоретичних досліджень, а й досвід участі працівників науково-методичного центру у комплексних об'єктових та командно-штабних навчаннях 3 органами управління та силами цивільного захисту територіальних підсистем ЄДСЦЗ у Львівській, Одеській, Житомирській, Черкаській, Миколаївській, Івано-Франківській, Полтавській, Запорізькій, Рівненській, Чернівецькій, Київській, Хмельницькій областях. В основу навчальних ситуацій було покладено інформацію про надзвичайні ситуації техногенного і природного характеру в Україні [1].

Окрім того, в основу моделювання роботи координуючих органів СДСЦЗ та відповідних навчально-методичних матеріалів було покладено реальний досвід участі розробників у засіданнях постійно діючих комісій техногенно-екологічної безпеки та надзвичайних ситуацій регіонального та місцевого рівня (далі - комісія ТЕБ та НС). 


\section{ЗАСТОСУВАННЯ ІНТЕРАКТИВНИХ ОСВІТНІХ ТЕХНОЛОГІЙ У НАВЧАННІ КЕРІВНОГО СКЛАДУ І ФАХІВЦІВ, ДІЯЛЬНІСТЬ ЯКИХ ПОВ'ЯЗАНА ЗОРГАНІЗАЦЕЮ ТА ЗДІЙСНЕННЯМ ЗАХОДІВЗ ПИТАНЬ ЦИВІЛЬНОГОЗАХИСТУ}

Такий збір даних проводився на постійній основі, і 3 цією метою була налагоджена активна співпраця $з$ посадовими особами підрозділів Управління з питань надзвичайних ситуацій КМДА, що безпосередньо забезпечують діяльність Постійної Регіональної комісії ТЕБ та НC, а в основу навчальних матеріалів, призначених для слухачів, закладено діючі нормативно-розпорядчі документи 3 організації роботи та прийнятих рішень зазначеної комісії. Розроблені навчально-методичні матеріали розглядались на наукових семінарах та проводились круглі столи за участі педагогічного складу мережі освітніх установ цивільного захисту, фахівців ДСНС України та посадових осіб місцевих органів державної влади. Таким чином отримувався зворотній зв'язок щодо шляхів вдосконалення змісту і структури підготовлених матеріалів, а також здійснювалась їх експертна оцінка.

Апробація навчально-методичного забезпечення для проведення заняття за методом аналізу конкретних навчальних ситуацій організовувалась в межах навчального процесу в Інституті державного управління у сфері цивільного захисту в рамках програм підвищення кваліфікації 3 наступними категоріями слухачів:

- педагогічних працівників навчальнометодичних центрів цивільного захистута безпеки життєдіяльності;

- державних службовців V - VII категорії посад;

- керівного складу і фахівців центральних і місцевих органів виконавчої влади, діяльність яких пов'язана $з$ організацією і здійсненням заходів 3 питань цивільного захисту.

Загальна структура роботи слухачів включала ознайомлення $з$ умовами кейсу, що є описом конкретної навчальної ситуації, вироблення рішення поставленої проблеми та презентацію результатів. Під час проведення занять викладач лише створював умови для активних дій i розвитку управлінських навичок, а вирішення проблемної ситуації слухачі здійснюють самостійно, демонструючи власну ініціативу i кмітливість. Рішенням були варіанти дій слухачів у ролі представників органів державної влади, спеціалізованих служб і формувань та аварійнорятувальних підрозділів, які присутні на засіданнях комісій ТЕБ та НС. Основною проблемою i одночасно засобом для ії вирішення $є$ ефективна комунікація між службами і відомствами при реагуванні на надзвичайні ситуації або загрози їх виникнення, яка забезпечує можливість вироблення індивідуальних та групових рішень для досягнення проміжних та кінцевих результатів.

При оцінці результатів роботи слухачів, на нашу думку найбільш доцільним, зважаючи на специфіку визначених завдань, є проблемний аналіз, центральним елементом якого є поняття проблеми. Проблемний аналіз передбачає певний ступінь усвідомлення сутності, специфіки тієї чи іншої проблеми і шляхів її вирішення.

Аналітична робота 3 застосуванням проблемного аналізу нами оцінювалась за наступними критеріями:

- доцільність пропозицій кожного учасника (члена комісії ТЕБ та НС) для прийняття остаточного рішення лідером групи (головою комісії ТЕБ та НС), відповідно до наданої ролі та передбачених законодавством повноважень;

- визначення просторових і часових меж надзвичайної ситуації;

- класифікація надзвичайної ситуації 3 використанням нормативно-правових актів у сфері цивільного захисту;

- здатність передбачити можливий розвиток надзвичайної ситуації на певній території;

- оцінка ризиків виникнення надзвичайної ситуації при існуючих загрозах;

- визначення ресурсів, які необхідні для ліквідації або запобігання надзвичайній ситуації;

- реальність і доцільність організаційноуправлінських рішень для запобігання, ліквідації або мінімізації наслідків надзвичайної ситуації;

- якість презентації результатів роботи групи.

На підставі проведених досліджень та апробацій підготовленого кейсу авторським колективом, як обов'язковий елемент впровадження кейс-методу, підготовлено практикум для педагогічних працівників навчально-методичних центрів цивільного захисту та безпеки життєдіяльності 3 проведення практичних занять за методом конкретних навчальних ситуацій при здійсненні функціонального навчання. Він складається з двох розділів: теоретичного у вигляді методичних рекомендацій та практичного, основою якого є навчально-методичні матеріали з проведення практичного заняття за методом аналізу конкретних навчальних ситуацій.

Розглянемо особливості проведення практичного заняття за методом аналізу конкретних навчальних ситуацій за темою “Координація діяльності, пов'язаної з техногенноекологічною безпекою, захистом населення і територій, запобіганням і реагуванням на надзвичайні ситуації".

Навчальною метою заняття визначено 


\section{ЗАСТОСУВАННЯ ІНТЕРАКТИВНИХ ОСВІТНІХ ТЕХНОЛОГІЙ У НАВЧАННІ КЕРІВНОГО СКЛАДУ І ФАХІВЦІВ, ДІЯЛЬНІСТЬ ЯКИХ ПОВ'ЯЗАНА З ОРГАНІЗАЦІЮ ТА ЗДІЙСНЕННЯМ ЗАХОДІВ З ПИТАНЬ ЦИВІЛЬНОГОЗАХИСТУ}

набуття слухачами і закріплення спеціальних знань $з$ питань координації діяльності органів державної влади в разі загрози або виникнення надзвичайної ситуації, а також формування навичок ефективної комунікації та прийняття рішення в кризових ситуаціях. Зміст кейсу починається з преамбули, в якій викладено події та обставини, що передували засіданню комісії ТЕБ та НС. Далі наводяться можливі наслідки при виникненні надзвичайної ситуації і прогнозовані природні умови, за яких може статися надзвичайна ситуація. Додатково слухачі забезпечуються інформаційним матеріалом стосовно особливостей надзвичайних ситуацій такого роду, а також робочими папками, що містять основні функції і завдання спеціалізованих служб органів управління цивільного захисту. Також визначені конкретні ролі учасників (голова та члени (керівники спеціалізованих служб) Постійної комісії з питань техногенно-екологічної безпеки та надзвичайних ситуацій) і завдання для слухачів:

1. Голові комісії визначитись із складом комісії ТЕБ та НС та їх основними завданнями, представити склад комісії. Враховуючи ймовірність виникнення, вид, рівень та характер надзвичайної ситуації, організувати засідання комісії ТЕБ та НС.

2. Членам комісії підготувати пропозиції в межах повноважень стосовно проведення необхідних заходів для запобігання виникненню та реагування на надзвичайну ситуацію (презентація кожним учасником прийнятого рішення).

3. Підготувати рішення за пропозиціями членів комісії стосовно необхідного обсягу заходів щодо реагування на загрозу або виникнення надзвичайної ситуації (презентація проекту рішення у вигляді протоколу засідання комісії).

Основним опорним документом, що містить дані про обсяг та наявні ресурси для належного забезпечення заходів цивільного захисту служить Навчальний план реагування органів управління та сил цивільного захисту при виникненні гідрологічних надзвичайних ситуацій (водопілля, паводки). В результаті учасники навчальних груп повинні представити складений ними Проект рішення (протокол комісії з питань техногенноекологічної безпеки та надзвичайних ситуацій) форма якого також надається слухачам.

Процес організації проведення заняття за методом аналізу конкретних навчальних ситуацій ми розподілили на два етапи. Бюджет часу, що відводиться для проведення заняття становить 4 академічні години (табл. 1).
На початку першого етапу відповідальним за його проведення оголошується програмна тема заняття, надається коментар стосовно форми його проведення, доводиться до слухачів навчальна мета та основні програмні питання, що складають зміст теми. Зі слухачами обговорюється порядок проведення заняття. Після визначення організаційних питань слухачам пропонується мінілекція за темою навчального заняття 3 використанням мультимедійних презентацій, аудіо-, відеоматеріалів.

В межах першого етапу заняття передбачено виконання слухачами міні-кейсів (коротких ситуаційних вправ) 3 метою адаптації учасників до подальшої роботи в групах та визначення лідерів навчальних груп. При підготовці серії різноманітних міні-кейсів нами використовувався досвід тренувальних заходів 3 практичного використання спеціальної методології для навчань експертів 3 реагування у разі виникнення масштабних надзвичайних ситуацій “МакСім”, розробленої шведськими вченими [11].

У процесі виконання коротких ситуаційних вправ необхідно здійснювати рольовий розподіл слухачів для роботи в підгрупах (по 5 - 6 осіб). Зміст групової вправи на першому етапі полягає у розборі декількох спеціально розроблених коротких ситуаційних завдань 3 проблемною ситуацією, яку необхідно вирішити колегіально. Ситуаційна вправа дає можливість слухачам занурюватися у спеціально створену реальну атмосферу професійного спілкування, дозволяє виконувати різноманітні ролі, допомагає розкривати комунікативні здібності та сприяє аналізу комунікативної діяльності (рис. 1).

В кінці проведення першого етапу заняття надаються коментарі та відповіді на запитання слухачів, підводяться підсумки першого етапу. Слухачі отримують інструкції та роздатковий матеріал на самопідготовку до основної частини заняття. Роздатковий матеріал може бути у вигляді карт, графіків, планів, інструкцій, алгоритмів, технічної документації або підготовленого заздалегідь теоретичного матеріалу у вигляді пакету документів, переліку необхідних нормативно-правових документів.

На початку проведення другого етапу проведення оголошується порядок проведення заняття, калькуляція відведеного часу. Зі слухачами обговорюються правила групової роботи. За допомогою мультимедійного проектора модератором висвітлюється текст навчальної ситуації та навчальні завдання. Текст навчальної ситуації та навчальні завдання зачитуються викладачем та супроводжуються 


\section{ЗАСТОСУВАННЯ ІНТЕРАКТИВНИХ ОСВІТНІХ ТЕХНОЛОГІЙ У НАВЧАННІ КЕРІВНОГО СКЛАДУ І ФАХІВЦІВ, ДІЯЛЬНІСТЬ ЯКИХ ПОВ' ЯЗАНА З ОРГАНІЗАЦІЕЮ ТА ЗДІЙСНЕННЯМ ЗАХОДІВ З ПИТАНЬЦИВІЛЬНОГО ЗАХИСТУ}

Таблиця 1.

Хід проведення заняття за методом аналізу конкретних навчальних ситуацій

\begin{tabular}{|c|c|c|}
\hline Етапи & Хід проведення заняття & Чac \\
\hline \multirow{4}{*}{$\begin{array}{l}\text { Організац } \\
\text { ійна } \\
\text { частина } \\
\text { заняття } \\
\text { (40 хв.) }\end{array}$} & $\begin{array}{l}\text { Оголошення викладачем теми заняття, форми проведення, навчальної мети, } \\
\text { основних програмних питань, порядку проведення, калькуляції відведеного часу }\end{array}$ & 5 хв. \\
\hline & Міні-лекція за темою навчального заняття & 10хв \\
\hline & $\begin{array}{l}\text { Рольовий розподіл слухачів для роботи в підгрупах (по 5-10 осіб) та виконання } \\
\text { групової коротких ситуаційних вправ }\end{array}$ & 15 хв. \\
\hline & $\begin{array}{l}\text { Отримання слухачами інструкцій та роздаткового матеріалу на самопідготовку до } \\
\text { основної частини заняття, коментарі та відповіді на запитання слухачів }\end{array}$ & $10 \mathrm{x}$ \\
\hline \multirow{8}{*}{$\begin{array}{l}\text { Основна } \\
\text { частина } \\
\text { заняття } \\
(120 \text { хв.) }\end{array}$} & $\begin{array}{l}\text { Оголошення викладачем порядку проведення заняття, калькуляції відведеного } \\
\text { часу, правил групової роботи. }\end{array}$ & 5 хв. \\
\hline & $\begin{array}{l}\text { Оголошення тексту навчальної ситуації (мультимедійна демонстрація } 3 \\
\text { поясненнями тексту навчальної ситуації та супровідних матеріалів, карт, схем). } \\
\text { Постановка навчальних завдань. }\end{array}$ & 10 хв. \\
\hline & \multicolumn{2}{|l|}{ Робота в групах над виробленням колегіального рішення (демонстрація відеоматеріалу) } \\
\hline & $\begin{array}{l}\text { Робота в групах по виконанню першого завдання та презентація результатів } \\
\text { лідером групи }\end{array}$ & $15 \mathrm{xB}$. \\
\hline & $\begin{array}{l}\text { Робота в групах по виконанню другого завдання та презентація результатів } \\
\text { учасниками групи }\end{array}$ & 20xв. \\
\hline & $\begin{array}{l}\text { Робота в групах по виконанню третього завдання та презентація результатів } \\
\text { роботи у вигляді протокольного рішення }\end{array}$ & $35 \mathrm{xB}$. \\
\hline & Групова дискусія, обговорення результатів роботи & 20xв. \\
\hline & $\begin{array}{l}\text { Оголошення викладачем оптимального варіанту вирішення навчальних завдань, } \\
\text { підведення підсумків }\end{array}$ & $15 \mathrm{xв.}$ \\
\hline
\end{tabular}

коментарями та поясненнями. Додатково слухачам видається вказана інформація на окремих аркушах паперу. Водночас за допомогою мультимедійного проектора на екрані висвітлюються довідкові матеріали, що використовуються слухачами для вирішення навчальних завдань (наприклад карти підтоплення місцевості) або відеоматеріал за тематикою заняття.

Робота в групах над виробленням колегіального рішення може відбуватись у формі дискусії, творчого обговорення або мозкового штурму. Використовуючи наявний роздатковий матеріал та опис навчальної ситуації, виходячи 3 навчальних завдань, слухачі обговорюють варіанти рішення, надають свої пропозиції та фіксують текст рішення для подальшого представлення. Викладач на даному етапі здійснює інформаційну підтримку, стежить за дотримання порядку виконання завдань. Якщо передбачається робота декількох груп, презентація наступної групи здійснюється послідовно після короткого виступу викладача, в якому звучить завдання доповнити або

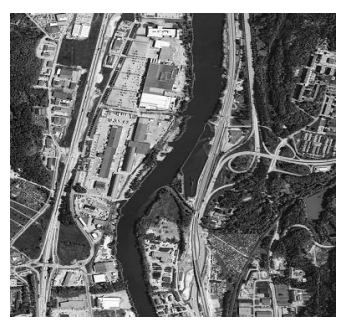

Понеділок 14.07.2016, місцевий час 16:48

Корабель Вікторія, зареєстрований в Одесі, сів на мілину на річці Дунай в районі міста

Кілія. У корпусі корабля з'явилася пробоїна, на кораблі спалахнула невелика пожежа.

Судно мало на борту 3000 тонн нафти $(3300$ m3) і іï мала частина просочилася в річку.

Розташування судна на річці унеможливлює прохід інших кораблів.

Річка Дунай є одним із джерел водопостачання для м. Кілія. За 500 м. від місця аварії знаходиться водопровідна станція.

Рис. 1. Приклад короткої ситуаційної вправи (“Корабель “Вікторія") 


\section{ЗАСТОСУВАННЯ ІНТЕРАКТИВНИХ ОСВІТНІХ ТЕХНОЛОГІЙ У НАВЧАННІ КЕРІВНОГО СКЛАДУ І ФАХІВЦІВ, ДІЯЛЬНІСТЬ ЯКИХ ПОВ' ЯЗАНА З ОРГАНІЗАЦЕЮ ТА ЗДІЙСНЕННЯМ ЗАХОДІВ 3 ПИТАНЬ ЦИВІЛЬНОГО ЗАХИСТУ}

спростувати результати роботи попередньої групи.

Після доповідей про результати навчальної діяльності керівник другого етапу практичного заняття провокує дискусію шляхом постановки проблемних питань. В процесі дискусії слухачі мають змогу обговорити виявлені в результатах роботи недоліки, знайти невідповідності та прорахунки допущені на етапі групової роботи. При підведенні підсумків керівник заняття аналізує хід та результати виконання завдань групи, оголошує оптимальний варіант виконання завдань (групового рішення), а також оцінює індивідуальні здобутки або недоліки учасників заняття.

Проаналізуємо результати впровадження практичного заняття 3 використанням методу аналізу конкретних навчальних ситуацій за темою: “Координація діяльності, пов'язаної з техногенноекологічною безпекою, захистом населення i територій, запобіганням і реагуванням на надзвичайні ситуації”.

Педагогічний експеримент проводився на базі Інституту державного управління у сфері цивільного захисту. 3 метою проведення педагогічного експерименту із числа фахівців центральних і місцевих органів виконавчої влади, діяльність яких пов'язана 3 організацією і здійсненням заходів цивільного захисту було підібрано експериментальну та контрольну групи, кожна група складалася 320 осіб. В експериментальній групі підготовка до проведення практичного заняття з використанням методу аналізу конкретних навчальних ситуацій за темою: “Координація діяльності, пов’язаної 3 техногенно-екологічною безпекою, захистом населення і територій, запобіганням і реагуванням на надзвичайні ситуаціі” була побудована на загальних принципах системності, активності, комплексності та індивідувальному підході до кожного учасника. Робота протягом проведення практичного заняття з використанням методу аналізу конкретних навчальних ситуацій в експериментальній групі була організована таким чином, що включала два етапи, період самостійної підготовки та групову роботу. Під час індивідуальних та групових форм роботи, учасники виконували завдання, що передбачали використання власного професійного досвіду та набутих знань, умінь і навичок в процесі підвищення кваліфікації. В контрольній групі зі слухачами практичне заняття з використанням методу аналізу конкретних навчальних ситуацій не проводилось.

Слід зазначити, що оцінку ефективності проведення практичного заняття з використанням методу аналізу конкретних навчальних ситуацій за темою: “Координація діяльності, пов’язаної $з$ техногенно-екологічною безпекою, захистом населення і територій, запобіганням і реагуванням на надзвичайні ситуації” ми проводили за когнітивним критерієм. Когнітивний критерій розглядається нами як сукупність знань 3 теми заняття, які необхідні для успішного здійснення професійної діяльності.

На підставі вищезгаданих критеріїв ефективності проведення практичного заняття розроблено авторську анкету “Дослідження ефективності проведення практичного заняття 3 використанням методу аналізу конкретних навчальних ситуацій за темою: “Координація діяльності, пов'язаної з техногенно-екологічною безпекою, захистом населення і територій, запобіганням і реагуванням на надзвичайні ситуації'. Опитування за допомогою цієї анкети проводилось у експериментальній та контрольній групах. Порівняльний аналіз результатів в експериментальній та контрольній групах показав наявність відмінностей між групами за показником володіння учасниками необхідними знаннями з теми заняття. Якщо в контрольній групі високий рівень цього показника демонстрували близько $10 \%$ респондентів, то в експериментальній високим рівнем цього показника характеризувалися більше половини (60\%) респондентів. Таким чином, підтверджується позитивний вплив проведення практичного заняття 3 використанням методу аналізу конкретних навчальних ситуацій за темою: “Координація діяльності, пов'язаної з техногенноекологічною безпекою, захистом населення i територій, запобіганням і реагуванням на надзвичайні ситуації” на підвищення рівня професійних знань керівного складу і фахівців, діяльність яких пов'язана 3 організацією та здійсненням заходів цивільного захисту.

Що стосується безпосередньо оцінки слухачами ступеню підвищення їхньої професійної компетентності після проведення практичного заняття за методом аналізу конкретних навчальних ситуацій, то $90 \%$ учасників вважають заняття “ефективним” або “скоріше ефективним”, $5 \%$ респондентів оцінюють кейс як “у рівній мірі ефективний i не ефективний”, лише $5 \%$ респондентів вважають кейс “скоріше неефективним" та жоден з учасників не описує проведене заняття як "неефективне".

За допомогою авторської анкети також здійснено аналіз ефективності практичного заняття в цілому. Розглянемо, насамперед, наскільки справдилися очікування учасників кейсу. Аналіз ефективності проведення 


\section{ЗАСТОСУВАННЯІНТЕРАКТИВНИХ ОСВІТНІХ ТЕХНОЛОГІЙ У НАВЧАННІ КЕРІВНОГО СКЛАДУ І ФАХІВЦІВ, ДІЯЛЬНІСТЬ ЯКИХ ПОВ'ЯЗАНА З ОРГАНІЗАЦІЕЮ ТА ЗДІЙСНЕННЯМ ЗАХОДІВ 3 ПИТАНЬ ЦИВІЛЬНОГО ЗАХИСТУ}

практичного заняття 3 використанням методу аналізу конкретних навчальних ситуацій в цілому показав, що три чверті (75\%) учасників зазначають, що їх очікування від проведення заняття “справдилися” або “скоріше справдилися”. Виявлено, що 10\% респондентів вважають, що їх очікування “і справдилися, і не справдилися”, $10 \%$ респондентів свідчать про те, що їх очікування “скоріше не справдилися" і лише 5\% опитаних зазначають, що їх очікування “не справдилися".

Оскільки три чверті учасників стверджують, що їх очікування справдилися цілком або значною мірою, це може свідчити про вдале проведення практичного заняття за методом аналізу конкретних навчальних ситуацій.

Висновки. Враховуючи особливості професійної діяльності фахівців сфери цивільного захисту, найбільш ефективними освітніми технологіями для формування необхідних компетентностей для сфери цивільного захисту є інтерактивні методи навчання 3 використанням інформаційнокомунікативних технологій.

Для більш глибокого й відповідно якісного вивчення програмної теми було розроблено та впроваджено в освітній процес навчальнометодичний інструментарій для проведення практичного заняття за методом аналізу конкретних навчальних ситуацій “Координація діяльності, пов'язаної з техногенно-екологічною безпекою, захистом населення і територій, запобіганнями і реагуванням на надзвичайні ситуаціі”.

В результаті проведення практичного заняття за методом аналізу конкретних навчальних ситуацій ми досягли головної педагогічної мети, a саме набуття слухачами і закріплення спеціальних знань $з$ питань координації діяльності органів державної влади в разі загрози або виникнення надзвичайної ситуації, а також формування навичок ефективної комунікації та прийняття рішення в кризових ситуаціях. Зміст кейсу починається з преамбули, в якій викладено події та обставини, що передували засіданню комісії ТЕБ та НС.

Високі оцінки учасників за результатами анкетування свідчать про ефективність проведення практичного заняття з використанням методу аналізу конкретних навчальних ситуацій за темою: “Координація діяльності, пов’язаної 3 техногенно-екологічною безпекою, захистом населення і територій, запобіганням і реагуванням на надзвичайні ситуацію”.

Доцільність подальших наукових досліджень 3 проблем впровадження кейс-технології в освітній процес вбачається у створенні динамічної навчальної моделі розвитку надзвичайної ситуації для відтворення засобами SMART Board під час проведення практичних занять за методом аналізу конкретних навчальних ситуацій.

\section{ЛІТЕРАТУРА}

1. Інформаційний бюлетень. Про надзвичайні ситуації техногенного та природного характеру в Україні за період з 1997 по 2006 роки (державний рівень). Дії органів управління та сил цивільного захисту з ліквідації надзвичайних ситуацій. № 2. Київ, 2008. 212 с.

2. Ковальова, С. М. Різноманітні підходи до класифікації кейсів. Вісник Житомирського державного університету імені Івана Франка №(74). 2014. pp. 20-24. ISSN 2076-6173.

3. Кодекс цивільного захисту України від 02.10.2012 р. № 5403-VI.

4. Психолого-педагогічні аспекти реалізації сучасних методів навчання у вищій школі: Навч. Посіб. / за ред. М.В.Артюшиної, О.М.Котикової, Г.М. Романової. Київ, 2007. С. 528.

5. Психологія і педагогіка. Проведення індивідуального заняття за методом аналізу конкретних навчальних ситуацій (case study): Навчально-методичний посібник - підготувала д-р філос.н. 3.Е. Скринник. Львів, 2012.145 с.

6. Постанова Кабінету Міністрів України від 09.01.2014 p. № 11 Про затвердження Положення про єдину систему цивільного захисту.

7. Постанова Кабінету Міністрів України від 09.10.2013 № 787 Про затвердження Порядку утворення, завдання та функції формувань цивільного захисту

8. Сурмін Ю. П. Кейс-метод: становлення та розвиток в Україні. Вісник Національної академії державного управління при Президентові України. 2015. № 2. C. 19-28. URL: http://nbuv.gov.ua/UJRN/ Vnadu_2015_2_5.

9. Смолянинова О.Г. Инновационные технологии обучения студентов на основе метода Case Study: Москва, 2000. с. 103-111.

10. Урбан М. А. Об использовании конкретных ситуаций (кейсов) для организации самостоятельной работы студентов в курсе "Методика начального обучения математике" / Материалы пятой международной научнопрактической конференции “Самостоятельная работа и академические успехи. Теория, исследования, практика". Минск, 2005. С. 126 132.

11. Lennquist Montán K., Khorram-Manesh A., Örtenwall P., Lennquist S.: Experiences from a new simulation model designed both for training and evaluation of methodology in major incident response. 


\section{ЗАСТОСУВАННЯ ІНТЕРАКТИВНИХ ОСВІТНІХ ТЕХНОЛОГІЙ У НАВЧАННІ КЕРІВНОГО СКЛАДУ І ФАХІВЦІВ, ДІЯЛЬНІСТЬ ЯКИХ ПОВ' ЯЗАНА ЗОРГАНІЗАЦЕЮ ТА ЗДІЙСНЕННЯМ ЗАХОДІВ З ПИТАНЬ ЦИВІЛЬНОГО ЗАХИСТУ}

Eur J Trauma Emerg Surg 2010; Suppl 1; s. 111.

\section{REFERENCES}

1. Pro nadzvychaini sytuatsii tekhnohennoho ta pryrodnoho kharakteru $v$ Ukraini za period $z$ 1997 po 2006 roky (derzhavnyi riven). Dii orhaniv upravlinnia ta syl tsyvilnoho zakhystu $z$ likvidatsii nadzvychainykh sytuatsii (2008) [On Emergencies of Technogenic and Natural Characteristics in Ukraine for the period from 1997 to 2006 (state level). Actions of the Civil Protection and Emergency Management and Civil Protection Force]. Kyiv, no. 2, 212 p. [in Ukrainian].

2. Kovalova, S. M. (2014). Riznomanitni pidkhody do klasyfikatsii keisiv [Various approaches to classifying cases]. Zhytomyr Ivan Franko State University Journal ISSN 2076-6173. Zhytomyr, no. 74, pp. 20-24. [in Ukrainian].

3. Kodeks tsyvilnoho zakhystu Ukrainy vid 02.10.2012 r. № 5403-VI. [Code of Civil Protection of Ukraine dated 02.10.2012 № 5403-VI]. [in Ukrainian].

4. Artiushyna, M.V., Kotykova, O.M. \& Romanova, H.M. (Eds.). (2007). Psykholohopedahohichni aspekty realizatsii suchasnykh metodiv navchannia $u$ vyshchii shkoli [Psychological-pedagogical aspects of the implementation of modern teaching methods in higher education]. Kyiv, 528 p. [in Ukrainian].

5. Skrynnyk, Z.E. (Ed). (2012). Psykholohiia $i$ pedahohika. Provedennia indyvidualnoho zaniattia za metodom analizu konkretnykh navchalnykh sytuatsii (case study) [Psychology and pedagogy. Conducting an individual lesson by the method of analysis of specific learning situations (case study)]. Lviv, 145 p. [in Ukrainian].

6. Postanova KMU vid 09.01.2014 r. № 11 Pro zatverdzhennia Polozhennia pro yedynu systemu tsyvilnoho zakhystu [Resolution of the Cabinet of Ministers of Ukraine dated January 9, 2014, No. 11
On Approval of the Regulation on a Unified System of Civil Protection]. [in Ukrainian].

7. Postanova Kabinetu Ministriv Ukrainy vid 09.10.2013 № 787 Pro zatverdzhennia Poriadku utvorennia, zavdannia ta funktsii formuvan tsyvilnoho zakhystu [Resolution of the Cabinet of Ministers of Ukraine dated 09.10.2013 № 787 On Approval of the Procedure for the Formation, Tasks and Functions of Civil Protection Formations]. [in Ukrainian].

8. Surmin, Yu. P. (2015). Keis-metod: stanovlennia ta rozvytok v Ukraini [Case method: formation and development in Ukraine]. Journal of the National Prosecution Academy of Ukraine. Kyiv, no. 2, pp. 19-28. [in Ukrainian].

9.Smolyaninova, O.G. (2000). Innovatsionnye tekhnologii obucheniya studentov na osnove metoda Case Study [Innovative technologies of teaching students on the basis of the Case Study method]. Collection "Innovations in Russian education". Moscow, pp. 103-111. [in Russian].

10. Urban, M. A. (2005). Ob ispolzovanii konkretnykh situatsiy (keysov) dlya organizatsii samostoyatelnoy raboty studentov v kurse "Metodika nachalnogo obucheniya matematike" [On the Use of Specific Situations (Cases) for Organizing Students' Independent Work in the Course "Primary Education in Mathematics"]. Materialy pyatoy mezhdunarodnoy nauchno-prakticheskoy konferentsii "Samostoyatelnaya rabota i akademicheskie uspekhi. Teoriya, issledovaniya, praktika"Proceedings of the Fifth International Scientific and Practical Conference "Independent Work and Academic Achievements. Theory, research, practice”. (pp. 126-132). Minsk. [in Russian].

11. Lennquist Montán, K., Khorram-Manesh, A., Örtenwall, P. \& Lennquist. S. (2010). Experiences from a new simulation model designed both for training and evaluation of methodology in major incident response. Eur J Trauma Emerg Surg. Suppl 1; p. 111. [in English].

Стаття надійшла до редакції 08.04.2019

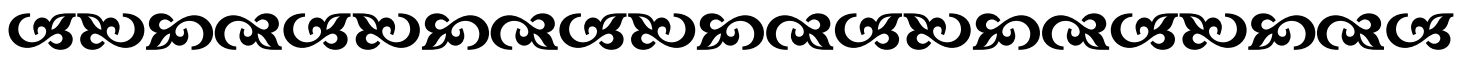

“Наші знання - це сума того, чого ми навчилися, й того, що ми забули”.

Марія бон Ебнер-Ешенбах австрійська письменниия

"Iз плодів вуст своїхлюдина насичується добром, $і$ за вчинки руклюдини нагорода iü".

Соломон пророк, иар давньої держави Ізраїль

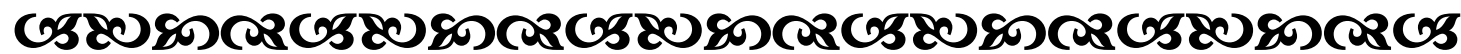

